\title{
Chemical control of signalgrass in alfalfa crops
}

\section{Controle químico do capim-braquiária em cultivo de alfafa}

\author{
Renan Coelho Dias ${ }^{1}$; Márcia Vitoria Santos ${ }^{2}$; Fabiana Lopes Ramos de Oliveira ${ }^{3 *}$; \\ Evander Alves Ferreira ${ }^{4}$; José Barbosa dos Santos; Bárbara Martins Rodrigues; \\ Cézar Augusto Martins ${ }^{6}$
}

\begin{abstract}
The use of herbicides to control grass in Medicago sativa (alfalfa) pastures is still incipient. Therefore, the objective of this study was to evaluate the efficiency of fluazifop-p-butyl in the control of Brachiaria decumbens (signalgrass) in alfalfa. Thus, randomized block design was used, with seven doses of fluazifop-p-butyl $\left(0,25,50,100,200,300,400 \mathrm{~g} \mathrm{ha}^{-1}\right)$, and four replications. Herbicide application was performed when the plants had about $20 \mathrm{~cm}$ height. Chlorophyll fluorescence, control of signalgrass and alfalfa toxicity were evaluated at 7, 15 e 30 days after application (DAA) and, at 45 DAA and 45 days after cut (DAC), both species were cut and tiller density, as well as branches and dry matter of forage species, were determined. Fluazifop-p-butyl does not affect the integrity of the photosynthetic apparatus of alfalfa plants, due to high tolerance to this mechanism of action presented by dicotyledonous species. However, signalgrass had physiological variables negatively affected by the herbicide, indicating the presence of physiological stress, even at the lowest doses of the product. The dose of $50 \mathrm{~g} \mathrm{ha}^{-1}$ of fluazifop-p-butyl is effective in controlling signalgrass, without causing physiological and growth damage in alfalfa plants.
\end{abstract}

Key words: Photosynthesis. Chlorophyll a fluorescence. Fluazifop-p-butyl. Medicago sativa. Electron transport rate.

\section{Resumo}

O uso de herbicidas no controle de gramíneas em pastagens de Medicago sativa (alfafa) ainda é incipiente, desse modo objetivou-se avaliar a eficiência do fluazifop-p-butil no controle de Brachiaria decumbens (capim-braquiária) em alfafa. Para tal utilizou-se o delineamento em blocos casualisados, com sete doses de fluazifop-p-butil $\left(0,25,50,100,200,300,400 \mathrm{~g} \mathrm{ha}^{-1}\right)$, e quatro repetições. A aplicação do herbicida foi realizada quando as plantas apresentavam cerca de $20 \mathrm{~cm}$ de altura. Foram realizadas avaliações de fluorescência da clorofila, controle do capim-braquiária e intoxicação da alfafa aos 7,15 e 30 dias após aplicação (DAA) e aos 45 DAA e 45 dias após o corte (DAC) ambas as espécies foram cortadas e determinadas a densidade de perfilhos e ramificações e a massa seca das espécies forrageiras. O fluazifop-p-butil não afeta a integridade do aparato fotossintético de plantas da alfafa, devido à grande

${ }^{1} \mathrm{Eng}^{\mathrm{o}} \mathrm{Agr}^{\circ}$, M.e em Zootecnia, Universidade Federal dos Vales do Jequitinhonha e Mucuri, UFVJM, Diamantina, MG, Brasil. E-mail: renanco@gmail.com

2 Prof $^{\mathrm{a}} \mathrm{Dr}^{\mathrm{a}}$ Zootecnista, Departamento de Zootecnia, CCA, UFVJM, Diamantina, MG, Brasil. E-mail: marciavitori@hotmail.com

$3 \mathrm{Dr}^{\mathrm{a}}$ em Zootecnia, Zootecnista, UFVJM, Diamantina, MG, Brasil.. E-mail: fabianalro@gmail.com

${ }^{4}$ Eng $^{\text {os }}$ Agr ${ }^{\text {os }}$, Drs. em Fitotecnia, UFVJM, Diamantina, MG, Brasil. E-mail: evanderalves@gmail.com; jbarbosasantos@yahoo. com.br

5 Discente, Curso de Mestrado, Programa de Pós-Graduação em Zootecnia, UFMG, Montes Claros, MG, Brasil. E-mail: babirodrigues@zootecnista.com.br

${ }_{6}^{6}$ Discente, Curso de Zootecnia, UFVJM, Diamantina, MG, Brasil. E-mail: cezarzootecnista@outlook.com

*Author for correspondence 
tolerância a esse mecanismo de ação apresentado por espécies dicotiledôneas. O capim-braquiária teve as variáveis fisiológicas afetadas negativamente pelo herbicida, indicando a presença de estresse fisiológico, mesmo nas menores doses do produto. A dose de $50 \mathrm{~g} \mathrm{ha}^{-1}$ de fluazifop-p-butil é eficiente no controle de capim-braquiária, sem causar danos fisiológicos e no crescimento de plantas de alfafa.

Palavra-chave: Fotossíntese. Fluorescência da clorofila a. Fluazifop p-butil. Medicago sativa. Taxa de transporte de elétrons.

\section{Introduction}

Medicago sativa (alfalfa) is used worldwide and is considered one of the main forage species, due to its adaptation to diverse edaphoclimatic conditions, high protein content, high digestibility and acceptance by animals, besides the high dry matter production and biological nitrogen fixation (PEREZ; DALL'AGNOL, 2009; LÉDO et al., 2004).

The use of new technologies, such as more responsive and better quality forage species in the production system, is fundamental for the increase in animal production. However, the substitution of species such as Brachiaria (Syn. Urochloa) by more productive species, such as alfalfa, is a difficult task, once some species of this genus (Brachiaria decumbens) have certain abilities that make them difficult to eradicate, since they can survive adverse factors (acidic soils, pest attacks, prolonged drought, fire and some cultural practices that aim at their control) (SANTOS et al., 2012), interfering in plant management (SANTOS et al., 2007, 2008, 2010; MELLO et al., 2000).

The difficulty in the control of Brachiaria decumbens is due to the lack of selective and registered herbicides for the control of forage species in pastures, and to the high operational cost of mechanical control methods. In this case, this forage species can be seen as a weed (SANTOS et al., 2007) and, in pastures grown with alfalfa, the competition for these undesirable plants can drastically reduce the production of the main crop (SILVA et al., 2005).

One of the herbicides used in the control of Brachiaria decumbens is fluazifop-p-butyl, which is a systemic herbicide, concentrating at the plant growth points, where they cause the inhibition of the enzyme acetyl-coenzyme A carboxylase (ACCase), essential for lipid biosynthesis (BURKE et al., 2006).

In studies of herbicide toxicity, it is important to evaluate the effects on growth and yield of the cultivated plant. However, the damage caused by herbicides is often not visible and the evaluation time is not sufficient to verify plant toxicity. In this case, the evaluation of physiological responses has been proposed by some researchers as a way of identifying the degree of plant toxicity (GALON et al., 2009, 2010; SILVEIRA et al., 2013; TORRES et al., 2012).

The evaluation of herbicide influence on plant physiology is measured by the damage caused to the photosynthetic apparatus, using equipment that measures chlorophyll a fluorescence, plant gas exchange, chlorophyll content and electron transport rate (GIROTTO et al., 2010). The assessment of fluorescence parameters is a non-destructive method and allows to analyze, qualitatively and quantitatively, the absorption and the use of light energy through photosystem II and the possible relationship with photosynthetic capacity (FERRAZ et al., 2014). Considering the photosynthetic process, light is absorbed by pigments of the antenna complex, which, excited, transfer energy to the reaction centers of photosystems I and II (P700 and P680, respectively) (YOUNG; FRANK, 1996). When excess energy occurs, it can be dissipated in the form of fluorescence (KRAUSE; WINTER, 1996). Thus, one of the methods of monitoring the inhibition or reduction in electron transfer between plant photosystems under stress, which 
can still be observed in intact leaves, is chlorophyll a fluorescence (MAXWELL; JOHNSON, 2000), where the reduction in energy dissipation by the photochemical process is reflected by the corresponding increase in fluorescence.

Thus, the objective of this study was to evaluate the efficiency of fluazifop-p-butyl in the control of Brachiaria decumbens cv. Basilisk (signalgrass) and identify the toxicity degree caused by the different doses of this chemical molecule in Medicago sativa (alfalfa), from the growth characteristics and physiological responses of the plants.

\section{Materials and Methods}

The experiment was carried out in a protected environment, on the JK Campus of Universidade Federal dos Vales do Jequitinhonha e Mucuri, in Diamantina-MG, located at $18^{\circ} 14^{\prime} 58^{\prime \prime} \mathrm{S}$ latitude and $43^{\circ} 36^{\prime} 01^{\prime \prime} \mathrm{W}$ longitude, with $1,183 \mathrm{~m}$ altitude and average annual temperature of $18.1{ }^{\circ} \mathrm{C}$. The climate is classified as $\mathrm{Cwb}$ (tropical altitude).

The treatments consisted of seven doses of fluazifop-p-butyl $(0,25,50,100,200,300,400 \mathrm{~g}$ $\mathrm{ha}^{-1}$ ) applied to Brachiaria decumbens (signalgrass) + Medicago sativa (alfalfa), cultivated in pots. The experimental design was in randomized blocks with four replications, due to the diverse conditions inside the greenhouse, mainly solar radiation.

Each plot consisted of a pot containing $2 \mathrm{dm}^{3}$ soil (Red-Yellow Oxisol, LVA), previously fertilized with $3 \mathrm{~g}$ single superphosphate, $1.5 \mathrm{~g}$ dolomitic limestone, $0.2 \mathrm{~g}$ potassium chloride and $0.3 \mathrm{~g}$ ammonium sulfate per $\mathrm{dm}^{3}$ soil (CANTARUTTI et al., 2007).

Signalgrass and alfalfa were sown directly in the pots, and thinning was done two weeks after germination, leaving two signalgrass plants interspersed with two alfalfa plants per pot. The other plant species that occurred in the pots were manually eliminated.
Plants were irrigated daily, maintaining soil moisture near $80 \%$ field capacity. Every 15 days, they were fertilized (side-dressing) with $1 \mathrm{~g}$ of formulation 20-05-20 (N-P-K) per pot.

The application of the herbicide was carried out using a costal sprayer equipped with a flat jet nozzle (XR 11002) at a constant pressure of $210 \mathrm{kPa}$, using a spray volume equivalent to $120 \mathrm{~L} \mathrm{ha}^{-1}$. The commercial product used was Fusilade $250 \mathrm{EW}$, at a concentration of $250 \mathrm{~g} \mathrm{~L}^{-1}$ fluazifop-p-butyl, applied 45 days after germination, when the plants of both species were about $20 \mathrm{~cm}$ high.

At 7, 15 and 30 days after application (DAA) of the herbicide, the photochemical efficiency of photosystem II was analyzed in alfalfa and signalgrass plants, using a fluorimeter (JUNIORPAM). The central leaflet of the first fully expanded leaf in alfalfa, located on the main branch of each of the plants per pot, was evaluated. In signalgrass, the first fully expanded leaf, with visible ligule and the most developed basal tiller was evaluated, avoiding the central leaf vein, in each of the plants of each pot. Chlorophyll fluorescence was measured after 30 minutes of adaptation to the dark, and the evaluations were performed at night, with emission of 0.3-s saturating light pulses, under a frequency of $0.6 \mathrm{KHz}$, allowing the determination of initial fluorescence $\left(\mathrm{F}_{0}\right.$ - electrons quantum $\left.{ }^{-1}\right)$, maximum fluorescence $\left(\mathrm{F}_{\mathrm{m}}\right.$ - electrons quantum $\left.{ }^{-1}\right)$, the ratio between variable and maximum fluorescence $\left(\mathrm{F}_{\mathrm{v}} /\right.$ $\mathrm{F}_{\mathrm{m}}$ - electrons quantum ${ }^{-1}$ ) and electron transport rate (ETR - $\mu$ mols electrons $\mathrm{m}^{-2} \mathrm{~s}^{-1}$ ).

At the same days of physiological characterization, control evaluations of signalgrass and toxicity levels of alfalfa were analyzed by visual observations, assigning scores from 0 to 100 , with 0 being the absence of control or toxicity, and 100 , the total control of the species or plant death, respectively, for signalgrass and alfalfa. This procedure was performed by two "blinded" evaluators (EWRC, 1964). 
At 30 DAA, plants of both species were harvested at ground level. The number of green (living) tillers was determined for signalgrass, and green branches for alfalfa. Subsequently, this material was taken to a forced air oven at $60{ }^{\circ} \mathrm{C}$, until constant weight, to determine the dry matter of each species.

After the cut, the pots continued to be irrigated and fertilized every 15 days, as described above, to evaluate the recovery capacity of plants submitted to different doses of the chemical molecule.

At 30 days after cut (DAC), the regrowth capacity of the plants was evaluated, performing a new cut and evaluating the same parameters quantified at 30 DAA.

The results were submitted to analysis of variance and the means to the Tukey test at 5\% probability. All analyses were performed using the statistical package SAS (Statistic Analysis System).

\section{Results and Discussion}

No difference was observed between the doses applied for initial fluorescence of chlorophyll $\left(\mathrm{F}_{0}\right)$, maximum fluorescence $\left(\mathrm{F}_{\mathrm{m}}\right)$, variable and average fluorescence ratio $\left(\mathrm{F}_{\mathrm{v}} / \mathrm{F}_{\mathrm{m}}\right)$ and electron transport rate (ETR- $\mu$ mols electrons $\mathrm{m}^{-2} \mathrm{~s}^{-1}$ ) (Table 1), at 7, 15 and 30 days after application (DAA) in alfalfa plants. This indicates that the herbicide fluazifop-p-butyl did not interfere in the integrity of the photosynthetic apparatus of alfalfa plants. It should be noted that dicotyledonous species are characterized by a high tolerance to acetyl-coenzyme A carboxylase(ACCase) inhibiting herbicides.

Table 1. Initial fluorescence $\left(\mathrm{F}_{0}\right)$, maximum fluorescence $\left(\mathrm{F}_{\mathrm{m}}\right)$, variable and average fluorescence ratio $\left(\mathrm{F}_{\mathrm{v}} / \mathrm{F}_{\mathrm{m}}\right)$ and electron transport rate (ETR- $\mu$ mols electrons $\mathrm{m}^{-2} \mathrm{~s}^{-1}$ ) of alfalfa plants submitted to doses of 0, 25, 50, 100, 200, 300, $400 \mathrm{~g} \mathrm{ha}^{-1}$ fluazifop-p-butyl, at 7, 15 and 30 days after application of the herbicide (DAA).

\begin{tabular}{|c|c|c|c|c|c|c|c|c|}
\hline \multirow{2}{*}{ DAA } & \multicolumn{8}{|c|}{ Fluazifop-p-butyl doses $\left(\mathrm{g} \mathrm{ha}^{-1}\right)$} \\
\hline & 0 & 25 & 50 & 100 & 200 & 300 & 400 & $\mathrm{CV}(\%)$ \\
\hline \multicolumn{9}{|c|}{$\mathrm{F}^{\mathrm{ns}}$} \\
\hline 7 & 111.7 & 100.0 & 114.3 & 138.3 & 126.3 & 117.0 & 122.5 & 8.54 \\
\hline 15 & 96.5 & 87.7 & 83.3 & 128.0 & 105.7 & 107.0 & 119.5 & 9.70 \\
\hline 30 & 99.7 & 96.3 & 112.7 & 106.0 & 94.5 & 70.7 & 98.0 & 10.47 \\
\hline \multicolumn{9}{|c|}{$\mathrm{F}_{\mathrm{m}}^{\mathrm{ns}}$} \\
\hline 7 & 520.3 & 483.3 & 550.3 & 613.5 & 590.5 & 537.3 & 582.0 & 5.61 \\
\hline 15 & 409.3 & 385.8 & 468.5 & 488.5 & 458.8 & 448.8 & 464.8 & 7.01 \\
\hline 30 & 401.5 & 456.3 & 485.5 & 434.3 & 425 & 361.2 & 398.9 & 7.39 \\
\hline \multicolumn{9}{|c|}{$\mathrm{F}_{\mathrm{v}} / \mathrm{F}_{\mathrm{m}}^{\mathrm{ns}}$} \\
\hline 7 & 0.785 & 0.795 & 0.792 & 0.775 & 0.785 & 0.785 & 0.790 & 2.47 \\
\hline 15 & 0.762 & 0.770 & 0.822 & 0.756 & 0.770 & 0.760 & 0.745 & 2.53 \\
\hline 30 & 0.761 & 0.785 & 0.762 & 0.752 & 0.780 & 0.775 & 0.790 & 2.52 \\
\hline \multicolumn{9}{|c|}{ ETR $^{\text {ns }}$} \\
\hline 7 & 31.7 & 20.5 & 29.2 & 23.1 & 29.7 & 27.1 & 25.5 & 11.03 \\
\hline 15 & 33.4 & 36.5 & 27.6 & 29.3 & 33.2 & 34.4 & 26.6 & 9.32 \\
\hline 30 & 28.7 & 29.2 & 26.6 & 33.0 & 32.4 & 39.1 & 27.6 & 9.51 \\
\hline
\end{tabular}

${ }^{\text {ns }}$ not significant by the Tukey test at $5 \%$. 
The effect of herbicides on the integrity of the electron transport rate in cassava plants was studied by Ferreira et al. (2015), who verified that fluazifopp-buthyl and chlorimuron caused low toxicity in the evaluated plants (also a dicotyledonous species) and did not alter the $\mathrm{F}_{\mathrm{v}} / \mathrm{F}_{\mathrm{m}}$ ratio or ETR.

When evaluating the effect of different doses of fluazifop-p-butyl on signalgrass plants, variations in all evaluated variables were observed, and this effect is dependent on the evaluation period (Table 2).

Table 2. Initial fluorescence $\left(\mathrm{F}_{0}\right)$, maximum fluorescence $\left(\mathrm{F}_{\mathrm{m}}\right)$, variable and average fluorescence ratio $\left(\mathrm{F}_{\mathrm{v}} / \mathrm{F}_{\mathrm{m}}\right)$ and electron transport rate (ETR- $\mu$ mols electrons $\mathrm{m}^{-2} \mathrm{~s}^{-1}$ ) of signalgrass submitted to doses of $0,25,50,100,200,300,400$ $\mathrm{g} \mathrm{ha}^{-1}$ fluazifop-p-butyl, at 7, 15 and 30 days after application of the herbicide (DAA).

\begin{tabular}{|c|c|c|c|c|c|c|c|c|}
\hline \multirow{2}{*}{ DAA } & \multicolumn{8}{|c|}{ Fluazifop-p-butyl doses $\left(\mathrm{g} \mathrm{ha}^{-1}\right)$} \\
\hline & 0 & 25 & 50 & 100 & 200 & 300 & 400 & $\mathrm{CV}(\%)$ \\
\hline \multicolumn{9}{|c|}{$\mathrm{F}_{0}$} \\
\hline 7 & $74.7 \mathrm{a}$ & $100.7 \mathrm{a}$ & $108.5 \mathrm{a}$ & $112.5 \mathrm{a}$ & $101.0 \mathrm{a}$ & $112.0 \mathrm{a}$ & $116.5 \mathrm{a}$ & 17.14 \\
\hline 15 & $61.7 \mathrm{~b}$ & $100.5 \mathrm{ab}$ & $119.0 \mathrm{ab}$ & $162.0 \mathrm{a}$ & $168.5 \mathrm{a}$ & $155.0 \mathrm{a}$ & $143.0 \mathrm{a}$ & 13.68 \\
\hline 30 & $56.5 \mathrm{a}$ & $51.5 \mathrm{a}$ & $54.25 \mathrm{a}$ & $76.0 \mathrm{a}$ & $71.5 \mathrm{a}$ & $48.0 \mathrm{a}$ & $47.3 \mathrm{a}$ & 31.5 \\
\hline \multicolumn{9}{|c|}{$\mathrm{F}_{\mathrm{m}}$} \\
\hline 7 & $345.5 \mathrm{a}$ & $283.0 \mathrm{a}$ & $369.3 \mathrm{a}$ & $402.7 \mathrm{a}$ & $345.3 \mathrm{a}$ & $398.5 \mathrm{a}$ & $308.5 \mathrm{a}$ & 10.99 \\
\hline 15 & $272.5 \mathrm{a}$ & $321.7 \mathrm{a}$ & $290.7 \mathrm{a}$ & $406.5 \mathrm{a}$ & $321.7 \mathrm{a}$ & $321.7 \mathrm{a}$ & $345.7 \mathrm{a}$ & 13.76 \\
\hline 30 & $304.7 \mathrm{a}$ & $174.5 \mathrm{ab}$ & $215.3 \mathrm{ab}$ & $160.3 \mathrm{ab}$ & $175.5 \mathrm{ab}$ & $102.0 \mathrm{~b}$ & $103.0 \mathrm{~b}$ & 21.82 \\
\hline \multicolumn{9}{|c|}{$\mathrm{F}_{\mathrm{v}} / \mathrm{F}_{\mathrm{m}}$} \\
\hline 7 & $0.782 \mathrm{a}$ & $0.642 \mathrm{a}$ & $0.707 \mathrm{a}$ & $0.717 \mathrm{a}$ & $0.705 \mathrm{a}$ & $0.717 \mathrm{a}$ & $0.622 \mathrm{a}$ & 6.92 \\
\hline 15 & $0.772 \mathrm{a}$ & $0.660 \mathrm{ab}$ & $0.597 \mathrm{ab}$ & $0.605 \mathrm{ab}$ & $0.557 b$ & $0.562 b$ & $0.542 b$ & 7.89 \\
\hline 30 & $0.815 \mathrm{a}$ & $0.760 \mathrm{ab}$ & $0.750 \mathrm{bc}$ & $0.580 \mathrm{~cd}$ & $0.602 \mathrm{~cd}$ & $0.502 \mathrm{~cd}$ & $0.395 \mathrm{~d}$ & 7.69 \\
\hline \multicolumn{9}{|c|}{ ETR } \\
\hline 7 & $26.0 \mathrm{a}$ & $16.2 \mathrm{a}$ & $16.9 \mathrm{a}$ & $16.1 \mathrm{a}$ & $22.4 \mathrm{a}$ & $18.4 \mathrm{a}$ & $15.4 \mathrm{a}$ & 61.4 \\
\hline 15 & $31.9 \mathrm{a}$ & $23.1 \mathrm{a}$ & $22.5 \mathrm{a}$ & $21.3 \mathrm{a}$ & $22.3 \mathrm{a}$ & $21.3 \mathrm{a}$ & $23.9 \mathrm{a}$ & 48.5 \\
\hline 30 & $26.5 \mathrm{a}$ & $31.3 \mathrm{a}$ & $25.2 \mathrm{ab}$ & $15.4 \mathrm{bc}$ & $11.1 \mathrm{c}$ & $12.5 \mathrm{c}$ & $10.5 \mathrm{c}$ & 60.8 \\
\hline
\end{tabular}

Means followed by the same letters in the row do not differ by the Tukey test at $5 \%$.

At 7 days after application of the treatments (DAA), there was no statistical difference between the doses of the product for the initial chlorophyll a fluorescence $\left(\mathrm{F}_{0}\right)$ in signalgrass, highlighting a small increase in the values of this variable. However, at 15 DAA, the $\mathrm{F}_{0}$ values observed at 0 $\mathrm{g} \mathrm{ha}^{-1}$ were lower than those found at doses higher than $100 \mathrm{~g} \mathrm{ha}^{-1}$ (Table 2). Higher $\mathrm{F}_{0}$ values may indicate that the herbicide fluazifop-p-butyl caused damage to the reaction centers of photosystem II, or compromised in the transport of excitation energy from the antenna complexes to the reaction centers (BOLHÀR-NORDENKAMPH et al., 1989). Nevertheless, this damage was indirect, once the mechanism of action of fluazifop-p-butyl is related to the inhibition of the enzyme ACCase, present in the initial phase of the lipid synthesis chain of lipids involved in the formation of cell membranes, considering the photosynthetic apparatus is present in the inner membranes of the thylakoids inside chloroplasts; thus, any chemical compound that affects the integrity or production of these internal 
membranes, affects the integrity of the electron transport-related apparatus in photosynthesis (TAIZ; ZEIGER, 2013).

According to Bolhàr-Nordenkamph et al. (1989), not always is $\mathrm{F}_{0}$ a constant, and its value may increase if PSII reaction centers are compromised, or if the transfer of excitation energy from the antenna to the reaction centers is impaired.

In this study, the $\mathrm{F}_{0}$ of the forage species did not show a significant difference, when comparing dose zero (control) to the other doses of the herbicide, in evaluations performed at 30 DAA (Table 2).

With respect to the maximum fluorescence $\left(\mathrm{F}_{\mathrm{m}}\right)$ of signalgrass, no difference was observed between herbicide doses at 7 and 15 DAA; on the other hand, at 30 DAA, a decrease in $F_{m}$ was observed for the averages of plots treated with the highest doses of the product: the values ranged from 304.7 electrons quantum $^{-1}$ in the control (without herbicide) to 103.0 electrons quantum ${ }^{-1}$ for the highest dose of fluazifop-p-butil (Table 2).

The ratio variable fluorescence/maximum fluorescence $\left(\mathrm{F}_{\mathrm{v}} / \mathrm{F}_{\mathrm{m}}\right)$ of signalgrass submitted to the application of fluazifop-p-butyl, showed no difference with the application of increasing doses of the product at 7 DAA. It was observed that, at 15 and 30 DAA, signalgrass plants showed a decrease in $\mathrm{F}_{\mathrm{v}} / \mathrm{F}_{\mathrm{m}}$ values with the increase in herbicide doses. Considering that plants in perfect physiological state, in the absence of stress, have a $F_{v} / F_{m}$ ratio ranging from 0.75 to 0.85 , it can be stated that signalgrass plants had their photosynthetic apparatus negatively affected at the lowest herbicide dose for evaluations at 7 and 15 DAA. However, at 30 DAA, $F_{v} / F_{m}$ values were lower than 0.75 from the herbicide dose at 100 $\mathrm{g} \mathrm{ha}^{-1}$ (Table 2).

The maximum quantum yield of PS II $\left(\mathrm{F}_{\mathrm{v}} / \mathrm{F}_{\mathrm{m}}\right)$ can range from 0.75 to 0.85 in non-stressed plants (BOLHÀR-NORDENKAMPH et al., 1989), and the reduction in this ratio is an excellent indicator of photoinhibitory effect when plants are submitted to chemical stress (ARAUS; HOGAN, 1994). Values lower than these indicate stress and reduction in the maximum quantum efficiency of photosystem II in signalgrass plants submitted to fluazifop-p-butyl and, consequently, a decrease in the photosynthetic potential of the plant.

The electron transport rate (ETR) of signalgrass plants did not show variation in the different doses of the herbicide at 7 and 15 DAA. However, at 30 DAA, there was a significant reduction in ETR values from the dose $100 \mathrm{~g} \mathrm{ha}^{-1}$, with a decrease in ETR values up to the highest dose evaluated (Table 2).

As ETR determines the rate of electron transport in PSII, using the value of this variable allows to detect the effect of herbicide performance at a very low concentration level, which was not the case for the results shown for fluazifop-p- butyl in signalgrass plants. This is due to the fact that the tested herbicide presents indirect action in the electron transport chain, affecting the synthesis of cell membrane constituents. However, the $\mathrm{F}_{\mathrm{v}}$ / $\mathrm{F}_{\mathrm{m}}$ parameter allows to detect this effect at a concentration level that is 100 times higher than that observed for ETR (ABBASPOOR et al., 2006), justifying the use of the methodology.

The minimum toxicity percentage of alfalfa by fluazifop-p-butyl was observed at $7 \mathrm{DAA}$ at the two highest herbicide doses, 300 and $400 \mathrm{~g} \mathrm{ha}^{-1}$, with respective values of 2 and $5 \%$; however, the plants recovered, showing no symptoms of toxicity at 15 and 30 DAA (Table 3 ). Toxicity values were in agreement with fluorescence values (Table 1), indicating the absence of stress in alfalfa plants treated with different doses of the herbicide. These results corroborate those observed by Mello et al. (2000), who describe that $200 \mathrm{~g} \mathrm{ha}^{-1}$ fluazifop-pbutyl were not toxic to alfalfa plants $15 \mathrm{~cm}$ high. Hijano et al. (2013) observed phytotoxicity above $70 \%$ in alfalfa plants with $20 \mathrm{~cm}$ height, between 14 and $21 \mathrm{DAA}$, at doses of 250 and $312.5 \mathrm{~g} \mathrm{ha}^{-1}$, decreasing the symptoms after 35 DAA. 
Table 3. Toxicity percentage of alfalfa plants submitted to doses of $0,25,50,100,200,300$ and $400 \mathrm{~g}^{-1}$ fluazifopp-butyl, at 7, 15 and 30 days after application (DAA).

\begin{tabular}{ccccccccc}
\hline \multirow{2}{*}{ DAA } & \multicolumn{8}{c}{ Fluazifop-p-butyl doses $\left(\mathrm{g} \mathrm{ha}^{-1}\right)$} \\
\cline { 2 - 8 } & 0 & 25 & 50 & 100 & 200 & 300 & 400 & $\mathrm{CV}(\%)$ \\
\hline 7 & $0 \mathrm{c}$ & $0 \mathrm{c}$ & $0 \mathrm{c}$ & $0 \mathrm{c}$ & $0 \mathrm{c}$ & $2 \mathrm{~b}$ & $5 \mathrm{a}$ & 0 \\
15 & $0 \mathrm{a}$ & $0 \mathrm{a}$ & $0 \mathrm{a}$ & $0 \mathrm{a}$ & $0 \mathrm{a}$ & $0 \mathrm{a}$ & $0 \mathrm{a}$ & 0 \\
30 & $0 \mathrm{a}$ & $0 \mathrm{a}$ & $0 \mathrm{a}$ & $0 \mathrm{a}$ & $0 \mathrm{a}$ & $0 \mathrm{a}$ & $0 \mathrm{a}$ & 0 \\
\hline
\end{tabular}

Means followed by the same letters in the row do not differ by the Tukey test at $5 \%$.

In relation to evaluations of signalgrass control with fluazifop-p-butyl (Table 4), it was observed that the percentage of control increased over time, with values above $70 \%$ at the two highest doses at
$15 \mathrm{DAA}$ and from $50 \mathrm{~g} \mathrm{ha}^{-1}$ at $30 \mathrm{DAA}$. At $30 \mathrm{DAA}$, it is already possible to observe the total death of signalgrass plants at 300 and $400 \mathrm{~g} \mathrm{ha}^{-1}$.

Table 4. Control percentage of signalgrass submitted to doses of 0, 25, 50, 100, 200, 300 and $400 \mathrm{~g}$ ha $^{-1}$ fluazifop-pbutyl, at 7,15 and 30 days after application (DAA).

\begin{tabular}{ccccccccc}
\hline \multirow{2}{*}{ DAA } & \multicolumn{7}{c}{ Fluazifop-p-butyl doses $\left(\mathrm{g} \mathrm{ha}^{-1}\right)$} \\
\cline { 2 - 8 } & 0 & 25 & 50 & 100 & 200 & 300 & 400 & $\mathrm{CV}(\%)$ \\
\hline 7 & $0 \mathrm{a}$ & $7.5 \mathrm{a}$ & $7.5 \mathrm{a}$ & $6.2 \mathrm{a}$ & $7.5 \mathrm{a}$ & $16.3 \mathrm{a}$ & $17.5 \mathrm{a}$ & 58.34 \\
15 & $0 \mathrm{c}$ & $48.5 \mathrm{ab}$ & $60.0 \mathrm{~b}$ & $60.0 \mathrm{~b}$ & $60.0 \mathrm{~b}$ & $73.7 \mathrm{c}$ & $75.0 \mathrm{c}$ & 9.95 \\
30 & $0 \mathrm{c}$ & $39.4 \mathrm{c}$ & $75.6 \mathrm{~b}$ & $75.0 \mathrm{~b}$ & $81.25 \mathrm{~b}$ & $100.0 \mathrm{a}$ & $100.0 \mathrm{a}$ & 7.26 \\
\hline
\end{tabular}

Means followed by the same letters in the row do not differ by the Tukey test at $5 \%$.

Similar results were found by Barroso et al. (2010), testing various ACCase inhibitors (clethodim, quizalofop-p-ethyl, fenoxaprop-p-ethyl, sethoxydim, tepraloxydim, fluazifop-p-butil and haloxyfop-methyl) in soybean, and found control values with fluazifop-p-butyl (125 $\left.\mathrm{g} \mathrm{ha}^{-1}\right)$ of $82 \%$ at 29 DAA in signalgrass plants with two tillers. On the other hand, haloxyfop-methyl (60 $\left.\mathrm{g} \mathrm{ha}^{-1}\right)$ yielded a control of $94 \%$ at 29 DAA, concluding that this class of herbicides (ACCase inhibitors) showed efficiency in the control of signalgrass and selectivity to the soybean crop, as no symptoms of injury were detected in the crop plants.

In other species, ACCase inhibitors also showed good control, as in the case of alexandergrass, with an average of $97 \%$ control of 4-leaf plants, using fluazifop-p-butyl (94 $\left.\mathrm{g} \mathrm{ha}^{-1}\right)$ and haloxyfopmethyl (60 $\mathrm{g} \mathrm{ha}^{-1}$ ) (GAZZIERO et al., 2000). For the control of Brachiaria brizantha cv. Marandu, in a Cynodon spp. (Tifton 85) pasture, Santos et al. (2012) observed that fluazifop-p-butyl was efficient in the control of this grass, with values of $71 \%$ with $94 \mathrm{~g} \mathrm{ha}^{-1}$ at 45 DAA. However, it caused high toxicity (51\%) in Tifton 85 plants.

The different doses of herbicide did not increase the number of alfalfa branches at 30 DAA (Table 5). At 30 DAC, there was an increase in the number of branches from $50 \mathrm{~g} \mathrm{ha}^{-1}$ (Table 5), possibly due to the control of signalgrass plants by the herbicide, eliminating the competition of plants grown in the same pot, similar to the values of the controls from the dose of $100 \mathrm{~g} \mathrm{ha}^{-1}$. 
Table 5. Number of green alfalfa branches (branch plant ${ }^{-1}$ ) and number of green signalgrass tillers (tiller plant ${ }^{-1}$ ) submitted to doses of $0,25,50,100,200,300,400 \mathrm{~g} \mathrm{ha}^{-1}$ fluazifop-p-butyl, at 30 days after application (DAA) and 30 days after cut (DAC).

\begin{tabular}{ccccccccc}
\hline \multirow{2}{*}{ Period } & \multicolumn{8}{c}{ Fluazifop-p-butyl doses $\left(\mathrm{g} \mathrm{ha}^{-1}\right)$} \\
\cline { 2 - 8 } & 0 & 25 & 50 & 100 & 200 & 300 & 400 & $\mathrm{CV}(\%)$ \\
\hline $30 \mathrm{DAA}$ & $2.5 \mathrm{a}$ & $3.5 \mathrm{a}$ & $2.5 \mathrm{a}$ & $2.5 \mathrm{a}$ & $3.3 \mathrm{a}$ & $4.3 \mathrm{a}$ & $4.3 \mathrm{a}$ & 17.5 \\
$30 \mathrm{DAC}$ & $7.0 \mathrm{a}$ & $3.75 \mathrm{~b}$ & $5.3 \mathrm{ba}$ & $5.3 \mathrm{ba}$ & $6.0 \mathrm{a}$ & $7.0 \mathrm{a}$ & $6.0 \mathrm{a}$ & 11.3 \\
\hline \multicolumn{7}{c}{ Signalgrass $\left(\right.$ tiller plant $\left.^{-1}\right)$} \\
\hline 30 DAA & $10.0 \mathrm{a}$ & $7.0 \mathrm{ab}$ & $4.5 \mathrm{~b}$ & $3.5 \mathrm{~b}$ & $2.3 \mathrm{~b}$ & $0.0 \mathrm{c}$ & $0.0 \mathrm{c}$ & 11.2 \\
$30 \mathrm{DAC}$ & $26.0 \mathrm{a}$ & $19.7 \mathrm{~b}$ & $0.0 \mathrm{c}$ & $0.0 \mathrm{c}$ & $0.0 \mathrm{c}$ & $0.0 \mathrm{c}$ & $0.0 \mathrm{c}$ & 8.2 \\
\hline
\end{tabular}

Means followed by the same letters in the row do not differ by the Tukey test at $5 \%$.

In relation to signalgrass tillering, a reduction with the increase in fluazifop-p-butyl doses at 30 DAA is observed up to the dose of $200 \mathrm{~g} \mathrm{ha}^{-1}$, which is due to the toxicity of the herbicidal molecule (Table 4 and 5). Signalgrass plants submitted to the two highest doses, 300 and $400 \mathrm{~g} \mathrm{ha}^{-1}$ at 30 DAA, did not present any live tiller, that is, they were totally dead. At $30 \mathrm{DAC}$, plants from $50 \mathrm{~g} \mathrm{ha}^{-1}$ fluazifop-p-butyl did not show any regrowth, which demonstrates the efficiency of herbicide control from that dose (Table 5).

Results similar to the number of tillers and branches were observed for dry matter production (Table 6), which was expected, since tillering/ branching is one of the characteristics inferred from the production of a forage species.

Table 6. Dry matter $\left(\mathrm{g}\right.$ plant ${ }^{-1}$ ) of signalgrass submitted to doses of $0,25,50,100,200,300,400,400 \mathrm{~g} \mathrm{ha}^{-1}$ fluazifopp-butyl, at 30 days after application (DAA) and 30 days after cut (DAC).

\begin{tabular}{ccccccccc}
\hline \multirow{2}{*}{ Period } & \multicolumn{7}{c}{ Fluazifop-p-butyl doses $\left(\mathrm{g} \mathrm{ha}^{-1}\right)$} \\
\cline { 2 - 9 } & 0 & 25 & 50 & 100 & 200 & 300 & 400 & $\mathrm{CV}(\%)$ \\
\hline $30 \mathrm{DAA}$ & $2.7 \mathrm{a}$ & $2.1 \mathrm{a}$ & $2.6 \mathrm{a}$ & $2.4 \mathrm{a}$ & $2.4 \mathrm{a}$ & $2.7 \mathrm{a}$ & $3.2 \mathrm{a}$ & 16.4 \\
\hline $30 \mathrm{DAC}$ & $3.5 \mathrm{a}$ & $1.9 \mathrm{c}$ & $2.7 \mathrm{~b}$ & $2.9 \mathrm{~b}$ & $4.1 \mathrm{a}$ & $4.2 \mathrm{a}$ & $3.6 \mathrm{a}$ & 12.9 \\
\hline \multicolumn{7}{c}{ Alfalfa $\left(\mathrm{g} \mathrm{plant}^{-1}\right)$} \\
\hline $30 \mathrm{DAA}$ & $6.9 \mathrm{a}$ & $5.1 \mathrm{a}$ & $1.5 \mathrm{~b}$ & $1.6 \mathrm{~b}$ & $1.3 \mathrm{~b}$ & $0.0 \mathrm{c}$ & $0.0 \mathrm{c}$ & 15.10 \\
\hline $30 \mathrm{DAC}$ & $3.6 \mathrm{a}$ & $1.85 \mathrm{~b}$ & $0 \mathrm{c}$ & $0 \mathrm{c}$ & $0 \mathrm{c}$ & $0 \mathrm{c}$ & $0 \mathrm{c}$ & 42.51 \\
\hline
\end{tabular}

Means followed by the same letters in the row do not differ by the Tukey test at $5 \%$.

These results indicate the possibility of using fluazifop-p-butyl in the control of signalgrass in alfalfa pasture, from $50 \mathrm{~g} \mathrm{ha}^{-1}$ fluazifop-p-butyl, without affecting the productivity of the forage species.

\section{Conclusion}

Fluazifop-p-butyl does not affect the integrity of the photosynthetic apparatus of Medicago sativa (alfalfa) plants, due to the great tolerance to this mechanism of action presented by dicotyledonous 
species. Brachiaria decumbens cv. Basilisk (signalgrass), a grass (Poaceae family), had its physiological variables negatively affected by the herbicide, indicating the presence of physiological stress, even at the lowest doses of the product.

The dose of $50 \mathrm{~g} \mathrm{ha}^{-1}$ fluazifop-p-butyl is efficient in the control of signalgrass, without causing physiological and growth damage to alfalfa plants.

\section{Acknowledgments}

The authors would like to thank Coordenação de Aperfeiçoamento de Pessoal de Nível Superior (CAPES), Conselho Nacional de Desenvolvimento Científico e Tecnológico (CNPq) and Fundação de Amparo à Pesquisa do Estado de Minas Gerais (FAPEMIG), for the financial support and grants provided.

\section{References}

ABBASPOOR, M.; TEICHER, H. B.; STREIBIG, J. C. The effect of root-absorbed PSII inhibitors on Kautsky curve parameters in sugar beet. Weed Research, Oxford, v. 46, n. 3, p. 226-235, 2006.

ARAUS, J. L.; HOGAN, K. P. Comparative leaf structure and patterns of photoinhibition of the neotropical palms. Scheelea zonensis and Socratea durissima growing in clearing and forest understory during the dry season in Panama. American Journal of Botany, St. Louis, v. 81, n. 6, p. 726-738, 1994.

BARROSO, A. L. L.; DAN, H. A.; PROCÓPIO, S. O.; TOLEDO, R. E. B.; SANDANIEL, C. R.; BRAZ, G. B. P.; CRUVINEL, K. L. Eficácia de herbicidas inibidores da accase no controle de gramíneas em lavouras de soja. Planta Daninha, Viçosa, MG, v. 28, n. 1, p. 149-157, 2010.

BOLHÀR-NORDENKAMPH, H. R.; LONG, R. S. P.; BAKER, N. R.; OQUIST, G.; SCHREIBER, U.; LECHNER, E. G. Chlorophyll fluorescence as a probe of the photossinthetic competence of leaves in the field: a review of current instrumentation. Functional Ecology, London, v. 3, n. 4, p. 497-514, 1989.

BURKE, I. C.; THOMAS, W. E.; BURTON, J. D.; SPEARS, J. F.; WILCUT, J. W. A seedling assay to screen aryloxyphenoxypropionic acid and cyclohexanedione resistance in Johnson grass (Sorghum halepense). Weed Tecnology, Champaign, v. 20, n. 4, p. 950-955, 2006.

CANTARUTTI, R. B.; BARROS, N. F.; PRIETO, H. E.; NOVAIS, R. F. Avaliação da fertilidade do solo e recomendação de fertilizantes. In: NOVAIS, R. F.; ALVAREZ, V. V. H.; BARROS, N. F.; FONTES, R. L. F.; CANTARUTTI, R. B.; NEVES, J. C. L. Fertilidade do solo. Viçosa, MG: Sociedade Brasileira da Ciência do Solo, 2007. p. 769-850.

EUROPEAN WEED RESEARCH COUNCIL - EWRC. Respost of three third and fouth Medetings of European Weed Research Council committee on methods. Weed Research, Oxford, v. 4, n. 1, p. 88-104, 1964.

FERRAZ, R. L. S.; BELTRÃO, N. E. M.; MELO, A. S.; MAGALHÃES, I. D.; FERNANDES, P. D.; ROCHA, M. $\mathrm{S}$. Trocas gasosas e eficiência fotoquímica de cultivares de algodoeiro herbáceo sob aplicação de silício foliar. Semina: Ciências Agrárias, Londrina, v. 35, n. 2, p. 735748, 2014.

FERREIRA, E. A.; MATOS, C. D. C.; BARBOSA, E. A.; SILVA, D. V.; SANTOS, J. B.; PEREIRA, G. A. M.; FARIA, A. T.; SILVA, C. T. Respostas fisiológicas da mandioca à aplicação de herbicidas. Semina: Ciências Agrárias, Londrina, v. 36, n. 2, p. 645-656, 2015.

GALON, L.; FERREIRA, F.; FERREIRA, E.; SILVA, A.; CONCENÇO, G.; SILVA, A. F.; REIS, M. R.; ASPIAZÚ, I.; FIALHO, C. M. T.; BARBOSA, M. H. P.; TIRONI, S. P. Tolerância de novos genótipos de cana-deaçúcar a herbicidas. Planta Daninha, Viçosa, MG, v. 28, n. 2, p. 329-338, 2010.

GALON, L.; FERREIRA, F. A.; FERREIRA, E. A.; SILVA, A. A.; SILVA, A. F.; ASPIAZÚ, I.; CONCENÇO, G.; FIALHO, C. M. T.; SANTOS, E. A.; TIRONI, S. P.; BARBOSA, M. H. P. Seletividade de herbicidas a genótipos de cana-de-açúcar. Planta Daninha, Viçosa, MG, v. 27, p. 1083-1093, 2009. Edição Especial.

GAZZIERO, D. L. P.; CHRISTOFFOLETI, P. J.; BRIGHENTI, A. M.; PRETE, C. E. C.; VOLL, E. Resistência da planta daninha capim-marmelada (Brachiaria plantaginea) aos herbicidas inibidores da enzima ACCase na cultura da soja. Planta Daninha, Viçosa, MG, v. 18, n. 1, p. 169-180, 2000.

GIROTTO, M.; ARALDI, R.; VELINI, E. R.; JASPER, S. P.; GOMES, G. L. G. C.; CARBONARI, C. A. Eficiência fotossintética da cana-de-açúcar após a aplicação dos herbicidas S-metolachlor e atrazine em pós-emergência. Revista Brasileira de Herbicidas, Londrina, v. 9, n. 3, p. 109-116, 2010.

HIJANO, N.; MONQUERO, P. A.; MUNHOZ, W. S.; GUSMÃO, M. R. Herbicide selectivity in alfalfa crops. 
Planta Daninha, Viçosa, MG, v. 31, n. 4, p. 903-918, 2013.

KRAUSE, G. H.; WINTER, K. Photoinhibition of photosynthesis in plants growing in natural tropical forest gaps: a chlorophyll fluorescence study. Botanica Acta, Stuttgart, v. 109, n. 6, p. 456-462, 1996.

LÉDO, F. J. D. S.; PEREIRA, A. P.; BOTREL, M. A.; SOBRINHO, F. S.; OLIVEIRA, J. S.; XAVIER, D. F.; HEINEMANN, A. B.; FERREIRA, R. P. Avaliação de cultivares de alfafa na Zona da Mata de Minas Gerais. Ciência e Agrotecnologia, Lavras, v. 28, n. 5, p. 11511159, 2004.

MAXWELL, K.; JOHNSON, G. N. Chlorophyll fluorescence: a practical guide. Journal of Experimental Botany, Oxford, v. 51, n. 345, p. 659-668, 2000.

MELLO, G.; REIS, R. A.; DURIGAN, J. C.; FERREIRA, L. R. Seletividade de herbicidas, aplicados em pósemergência, às plantas de alfafa. Planta Daninha, Viçosa, MG, v. 18, n. 2, p. 323-330, 2000.

PEREZ, N. B.; DALL'AGNOL, M. Características morfológicas de plantas de alfafa relacionadas à aptidão ao pastejo. Revista Brasileira de Zootecnia, Viçosa, MG, v. 38, n. 3, p. 418-421, 2009.

SANTOS, M. V.; FERREIRA, F. A.; FREITAS, F. C. L.; IKEDA, A. K.; OLIVEIRA, F. L. R.; ROCHA, D. C. C.; LIMA, J. G. V.; SILVA, F. N. A.; ASSIS, F. G. V. Tolerância do Tifton 85 (Cynodon spp.) e da Brachiaria brizantha ao Glyphosate. Planta Daninha, Viçosa, MG, v. 26 , n. 2 , p. $353-360,2008$.

SANTOS, M. V.; FERREIRA, F. A.; FREITAS, F. C. L.; TUFFI SANTOS, L. D.; VIANA, J. M.; ROCHA, D. C. C.; FIALHO, C. M. T. Controle de Brachiaria brizantha, com uso do glyphosate, na formação de pastagem de Tifton 85 (Cynodon spp.). Planta Daninha, Viçosa, MG, v. 25 , n. 1 , p. $149-155,2007$.
SANTOS, M. V.; FREITAS, F. C. L.; FERREIRA, F. A.; CARVAlHO, A. J.; BRAZ, T. G. S.; CAVALI, J.; RODRIGUES, O. L. Tolerância do Tifton 85 ao glyphosate em diferentes épocas de aplicação. Planta Daninha, Viçosa, MG, v. 28, n. 1, p. 31-137, 2010.

SANTOS, M. V.; FERREIRA, F. A.; FREITAS, F. C. L.; FONSECA, D. M.; CARVALHO, A. C.; BRAZ, T. G. S. Brachiaria brizantha control by using fluazifop-p-butil on Tifton 85 pasture formation. Revista Brasileira de Zootecnia, Viçosa, MG, v. 41, n. 2, p. 281-285, 2012.

SILVA, W.; VILELA, D.; COBUCCI, T.; HEINEMANN, A. D.; REIS, F. A.; SANTOS, R. A.; PEREIRA, A. V. Uso potencial de misturas de herbicidas no controle de plantas daninhas em alfafa. Revista Ceres, Viçosa, MG, v. 52, n. 299, p. 23-32, 2005.

SILVEIRA, H. M.; FERREIRA, E. A.; SILVA, D. V.; CASTRO NETO, M. D.; CARVALHO, F. P. V.; SANTOS, J. B.; SILVA, A. A. Características fisiológicas de cultivares de mandioca após aplicação do mesotrione. Planta daninha, Viçosa, MG, v. 31, n. 2, p. 403-409, 2013.

TAIZ, L.; ZEIGER, E. Fisiologia vegetal. 5. ed. Porto Alegre: Artmed, 2013. 954 p.

TORRES, L. G.; FERREIRA, E. A.; ROCHA, P. R. R.; FARIA, A. T.; GONÇALVES, V. A.; GALON, L.; SILVA, A. F.; SILVA, A. A. Alterações nas características fisiológicas de cultivares de cana-de-açúcar submetida à aplicação de herbicidas. Planta Daninha, Viçosa, MG, v. 30, n. 3, p. 581-587, 2012.

YOUNG, A. L.; FRANK, H. A. Energy transfer reactions involving carotenoids: quenching of chlorophyll fluorescence. Journal of Photochemistry and Photobiology B: Biology, Moscow, v. 36, n. 1, p. 3-15, 1996. 